\title{
Supporting Associate Teaching and Mentoring of Teacher Candidates: Building a Community of Practice
}

\author{
Karen Roland and Clinton Beckford \\ Faculty of Education, University of Windsor, Canada
}

\begin{abstract}
Associate teachers play a significant role in the preparation of pre-service teachers in Canadian universities. The literature on the subject indicates that the practicum component of the pre-service teacher education is considered by teacher candidates to be their most valuable learning experience. Therefore, Faculties of Education are constantly exploring new ways of engaging associates in re-imagining their role and clarifying expectations and support from the faculty. This paper presents preliminary findings from a survey of associate teachers conducted by the Faculty of Education at a mid-size, comprehensive university in south-western Ontario, Canada. The survey explored the perceptions of associate regarding their role, and sought feedback on supports that the faculty could offer strengthen the triumvirate relationship in teacher education. The study found that associates enthusiastically embrace their role as mentors and/or experiential learning specialists, and recommended closer ties with faculty personnel as collaborative opportunities with which to develop a community of practice in teacher education.
\end{abstract}

\section{Introduction}

Associate teachers play a significant role in the professional and social development of teacher candidates. The University of Windsor, Faculty of Education, Ontario, Canada, values the opportunity to actively collaborate and consult with associate teachers in an effort to continually improve the field experience component of its pre-service teacher education program. To this end, the Faculty of Education sought the perspectives of associate teachers in the four school boards in which teacher candidates complete the practice teaching component of their Bachelor of Education degree, concerning their role. A review of extant literature was conducted to explore teachers' perceptions of their role as associate teacher, the support the faculty advisor may be able to provide to them as associate teachers, and finally, recommendations from associates concerning strategies to strengthen the triumvirate relationship among the associate teacher, the teacher candidate, and the faculty advisor.

The triumvirate relationship in teacher education may be characterized as a learning partnership in a community of practice. The success of this partnership relies heavily on the facility of the associate teacher to coach, mentor, and to facilitate and supervise the teacher candidate in their development as teaching professionals [5]. This article will discuss a research study carried out to explore the perspectives of associates regarding the nature of the relationship between the associate teacher, teacher candidate, and the faculty advisor.

The study was undertaken as Beck and Kosnik suggest, as an inquiry to identify potential strategies and/or recommendations that may strengthen this relationship further [1]. In the practicum model operated by the University of Windsor, Faculty of Education, the relationship between teacher candidates, associate teachers and faculty advisors is envisaged as a community of practice. Within this triumvirate, the relationship between associate and teacher candidate has been identified as critical to successful teaching practice during field experience [4]. While most literature reflects an emphasis on associate and teacher candidate relationships, there is compelling evidence from this research, and the literature, that the relationship between associates and faculty is deserving of greater attention. The study findings underscore the importance of clarifying the expectations of the associate role, as significant to the benefit of all stakeholders.

\section{Literature review}

The field experience component of teacher education provides teacher candidates with opportunities to engage in the application of pedagogical theory in practice. As 'praxis,' field 
experience involves the development of teaching practice through the application of pedagogy in a meaningful context - the classroom. This 'real life' application of knowledge gained through experience in the classroom is supportive of the development of teacher efficacy in professional practice, and what Osterman purports is also necessary for the development of reflective practice [12]. Osterman asserts that reflective practice must emphasize the importance of theory and ideas, as well as experience and reflection, to actively create better schools - to challenge teachers, novice and seasoned, to examine the ideas that shape our schools, in an effort to actively reconstruct and restructure the "underlying mindscape" currently existing therein $[12 ; 151]$.

Linking the art of reflection with professional practice, involves a kind of knowing developed under the tutelage of experienced professional practitioners such as associate teachers [12]. Osterman further contends that universities may play an important function in fostering reflective practice, thereby creating learning partnerships that invite consultation and collaboration with which to critically examine the social reality of the classroom. Goodnough, Osmond, Dibbon, Glassman and Stevens assert that teacher education programs must facilitate a community of practice by offering a variety of learning experiences to assist teacher candidates in their transition from the periphery, to full membership in the community of educators [6]. Furthermore, they state that approaches to teacher education which integrate theory and practice through the pre-service experience, assist in developing the knowledge and skills necessary in a professional community of educators. It may be that co-learning in a teaching community of practice would afford the members of the triumvirate (associate teacher, teacher candidate, faculty), with what Wenger and Snyder identify as an opportunity to actively share experiences and knowledge in creative ways [19].

Strengthening the triumvirate relationship in the field experience component of teacher education may encourage reflective practice, and promote collaboration between school partners and universities to guide and mentor the future generations of professionals entering the teaching profession. Beck and Kosnik offer two broad conceptions or models of the associate role: the "critical interventionist model" approach involving reciprocal learning and a team teaching approach incorporating feedback and direct intervention on the part of the associate; and, the "practical initiation model," which defines teacher education as a practical initiation or apprenticeship model $[1 ; 208]$.

Beck and Kosnik state that associates who advocate for a critical interventionist model approach the practicum along a continuum of support ranging from nurturance, to directly challenging the teacher candidate - the operative aspect of the associate role being defined as a need to encourage teacher candidates with considerable advice, feedback and suggestions for improvement [1]. Additionally, they indicate that this interventionist stance requires that the associate interrupt teacher candidates as they teach, when deemed necessary. However, Beck and Kosnik also claim that associates advocating for a practical initiation model, view their role from a more practical standpoint as supporting teacher candidates through the process of experiential learning.

As associate teachers are "generally considered the holders of more knowledge and able to share that with students teachers" [5; 790], through their guidance, teacher candidates may gain confidence as a learner and beginning teacher. And yet, Beck and Kosnik point out that teacher education is strongly influenced by whichever focus the associate teacher adopts in the facilitation of their role as a member of the triumvirate relationship [1]. And because of this influence, they contend that if the goals of teacher education are to transform teaching and learning, there is a need to move beyond an apprenticeship model of teacher education, and to embrace a critical, dialogical approach to collaboration among the members of the triumvirate relationship.

In their research study Beck and Kosnik noted that many associates focused on the practicalities of teacher education, they emphasized the need for teacher candidates to learn about the 'realities' of teaching [1]. They argued that this finding highlights the need to foster reflective practice and reciprocal approaches to learning in the field experience component of teacher education. Additionally, in questioning the orientation of the role the associate adopts, there is also a need to consider the conflict between the mentorship role, and the evaluative aspect of the associate role in assessing the teaching practice of teacher candidates.

Associate teachers sometimes report stress and anxiety associated with their role in the field experience component of teacher education, and the literature suggests that the collaborative relationship between the associate and faculty personnel may assist in alleviating some of this anxiety. As an example, MacDonald, Baker and Stewart opine that the stress associates experience during teaching practice could be reduced through closer contact with faculty personnel [9]. However, Viskovic, suggests that participation in a community of practice, “... has implications for understanding and supporting learning" [18; 326], and that, "for communities, learning is an issue of refining their practice and ensuring new generations of members" [18; 326]. 
Therefore, as Beck and Kosnik assert, there is a need to not only clarify the role and expectations of associate teachers, but also a need to ensure that teacher education programs are working in concert with associates in the field [1].

In the remainder of this article, the methods utilized in a research study conducted with associate teachers are reported, along with a discussion of the results with particular focus on the findings relevant to the perceptions of associates in terms of their role, and the support their university partners in faculties of education may provide to them in carrying out this role.

\section{Methods and results}

The University of Windsor, Faculty of Education practicum model integrates coursework with field placements throughout the pre-service program. This model utilizes multiple placement blocks in elementary and secondary schools; these blocks are usually three to four weeks in duration. Each teacher candidate is assigned a faculty advisor who supervises their practicum experiences throughout the program, and candidates are also placed with an associate/mentor teacher in each teaching practice placement. The Field Experience Handbook outlines the expectations of the roles of the associates and faculty advisors. The expectations of associates are to act as mentors and coaches by providing modelling, practice, and support in a number of varied and integrated areas, including: orientation, observation, teaching practice and providing feedback [17]. The faculty advisor acts as a liaison between the school and the Faculty of Education, maintains regular contact with their advisees throughout the year including regular individual and group meetings, and visits them in the schools during their practicum placements [17]. As teacher educators, the roles of associates and advisors intersect in their collaborative and consultative engagement to integrate theory in practice - praxis in teacher education.

In spring 2008, associate teachers who participate in the field experience component of the pre-service teacher education program were invited to respond to a Faculty of Education associate teacher survey. The survey sample population comprised approximately 947 associate teachers employed with four local school boards. The final participant response to the survey was 134 associate teachers, or $14.2 \%$ of the total sample. Of the $67.2 \%$ of teacher participants who responded, $68.9 \%$ identified as female, and $31.1 \%$ as male. Similarly, of the $67.2 \%$ of the total associate teacher participants who responded, $15.5 \%$ indicated that they had 0-5 years teaching experience, $35.6 \%$ indicated $6-10$ years experience, and $48.9 \%$ indicated 11 years or more of teaching experience. Additionally, $67.9 \%$ of the teacher participants responded identifying the range of their experience as associate teachers working with the field experience program as $60.4 \%$ having $0-5$ years experience, $27.5 \%$ having $6-10$ years, $12.1 \%$ having 11 years or more experience. The mean number of years of participation in the field experience program was reported as 5.6 years, and the median number of years was reported as 4.0 years.

The anonymous and confidential online survey, the Associate Teacher Feedback: Anonymous \& Confidential Questionnaire, was developed to investigate issues, from the perspective of associate teachers. The survey was adapted from the work of Beck and Kosnik [1, 2]; Duquette [3]; Faire [4]; Joong [7]; Macdonald, Baker and Stewart [9]; Mujawamariya [10], Neil [11]; and Tuckman [15]. The questionnaire was constructed in three specific sections to obtain associate teachers' perspectives concerning: 1) their role as an associate teacher; 2) the role of the faculty advisor to support the associate teacher; and, 3) the benefits, as well as disadvantages associate teachers report in having a teacher candidate in their classroom. A variety of questioning styles were utilized including: openended questions which invited associate teachers to share their thoughts and insights; questions that asked associate teachers to rank order variables in terms of their importance; and finally, questions that asked associate teachers to respond to a number of statements indicating to what extent they agreed or disagreed. In accordance with research ethics considerations, anonymity and confidentiality were strictly observed.

Preliminary findings suggest that associate teachers enthusiastically support teacher candidates as newcomers to the teaching profession. The first section of the survey asked respondents the following: 1) to define the role of the associate teacher; 2) to rank those aspects which support the associate teacher role; and, 3) to answer various questions pertaining to the field experience component of the practicum including: the selection of associates, collaborative partnership with the faculty, and questions examining the mentorship versus apprenticeship model of teacher education. At the conclusion of this first section of the survey, associates were asked questions regarding how the Faculty of Education could improve the pre-service program, the field experience program, and strengthen the triumvirate relationship (associate teacher, teacher candidate, faculty advisor).

Participants responded to the first portion of this section of the survey by defining the 'role' of the associate teacher. Participant responses were 
classified into two categories or approaches to the associate teacher role: 1) that of mentor (modeling/coaching/reciprocal learning to nurture and support the success of teacher candidates); and 2) experiential learning specialist (providing the reality of classroom experience/sharing pedagogical techniques and skills). Of particular interest was the examination of the mentorship or coaching aspect of the associate role reported by the participants. Responses from the participants ranged from such statements as: "The role of an associate teacher is to first model expected teaching practices.... There is always give and take involved," and to other statements which identified a need to foster the relationship between teacher candidate, associate teacher, and the faculty by stating that, "the role of the associate teacher is to mentor teacher candidates, maintain a positive liaison between the school and the Faculty of Education..." The study results indicate that approximately $95 \%$ of the sample saw coaching as an important aspect of the associate teacher's role. Further, results showed almost $85 \%$ thought that the associate teacher should be a professional expert. Further, associates identified that their role incorporated the need to, "model excellent planning, teaching and classroom management practices ...critique teacher candidates in order to facilitate the candidate's growth in all areas."

These findings were very interesting given that the other category of responses highlighted the role of the associate teacher as an experiential learning specialist. This was illustrated in the participant statement which defined the field placement as "...the 'real' element of their [teacher candidates] year at the faculty,".....and a participant stating that teacher candidates, "... are bombarded for a year with 'theory' but what they need is reality. The classroom is Ground Zero." In the same vein another respondent described the associate role in terms of giving teacher candidates, "a view of what the real job of teaching is." This finding is particularly compelling given that approximately $60 \%$ of respondents either 'strongly disagreed' or 'disagreed,' with the statement that the Faculty of Education adequately prepares teacher candidates for the 'realities' of day-to-day classroom teaching. These findings suggest that there is a serious disconnect between theory and practice - praxis in teacher education. It also suggests a particular mindset on the part of many associate teachers and teacher candidates, in which the practicum is separated from the coursework component, and not seen as part of the faculty experience.

In the next section of this portion of the survey, associates were asked to rank the following variables in terms of the support they offer to the associate teacher role: orientation for associate teachers; recognition of the work involved in being an associate teacher; opportunities for associate teacher professional development; the availability of release time for associates to collaborate on projects; provision of faculty/university contact information; the opportunity for associates to consult with the faculty advisor and the teacher candidate; and, an 'other' option which the respondents identified.

The findings of the study indicate that providing orientation for associate teachers concerning the expectations of their role in the practicum, including protocols and evaluation procedures, was deemed the most supportive aspect by the associate participants. Opportunities for professional development were next in rank order, followed by the ability of associates to consult with teacher candidates and their faculty advisors. Release time to provide the opportunity to collaborate with the University was ranked next, followed closely by the provision of contact information - contact information for both the faculty advisor as well as the Field Experience office. Of these six variables, recognition for the associate teacher role was ranked lowest.

The variable category, 'Opportunities for Professional Development' was further expanded to inquire with participants concerning their perceptions of the most interesting professional development topics. The findings indicated the respondents' overwhelming interest, almost $80 \%$ indicating interest, in the topic of mentoring and coaching skills development for associate teachers. This was considered a confounding finding given that more than $50 \%$ of the associate respondents characterized the field experience program as an apprenticeship model rather than a mentorship relationship.

The survey also shed light on associate perspectives concerning recommendations to improve the pre-service program, the field experience practicum, and to strengthen the triumvirate relationship of teacher candidate/associate teacher/faculty advisor. There was congruency in the findings for all three of these areas. Associate comments suggested a need to clarify expectations as indicated in the following participant response, "There should be a meeting with the Faculty of Education professors and the Field Experience office to tell us what the Faculty's expectations are for the associate teacher." Additionally, the need to develop stronger links between course work and practicum through the development of relationships between faculty and school partners was clearly communicated in the following participant statement, "Associate teachers want to help teacher candidates make connections between their course work and the practicum. 
Faculty needs to encourage a stronger relationship with associate teachers in order to fulfill this."

Associates also noted the importance of assessment in the classroom, and that teacher candidates require more experience and exposure to this aspect of pedagogy. And lastly, with regard to the role of associate teachers, the participants recommended development of closer ties with the faculty advisor facilitated through additional school visits and opportunities for conferencing. This was a recurrent theme throughout the findings of the study - the need for greater consultation and collaboration between associates and the Faculty of Education. Addressing these findings may assist in strengthening the relationship among the members of the triumvirate, and thereby promoting a community of practice in teacher education.

\section{Discussion}

The study findings highlight the need to clarify the expectations of the associate role through orientation and closer collaboration with faculty personnel. As stated earlier, two conceptions of the associate role were identified in this study: one characterized as that of a mentor - the associate modeling, coaching and supporting the success of teacher candidates in a reciprocal learning process; and the other, that of an experiential learning specialist who provides the 'apprentice' with the opportunity to experience the 'realities' of the classroom.

The importance of the mentorship model in the field experience component of teacher education cannot be understated. Beck and Kosnik conducted research to ascertain the perceptions of student teachers concerning what components they identified as comprising a 'good' practicum placement [2]. In the discussion of their study, they indicate that the level of importance student teachers ascribed to relational aspects was more than they had anticipated. Specifically, they noted that student teachers reported that it was very important to have emotional support from their associate/mentor teacher during the practicum, and furthermore, they also wanted to be viewed as teachers within the learning community.

The University of Western Ontario's Continuing Education document, Mentoring: Tips and Ideas for Teachers and Administrators, defines the role of the associate/mentor teacher as both simple and complex given that each participant brings their own set of expectations, experiences, and needs to the mentorship relationship [16]. This requires that participants navigate the relationship by listening for understanding, and recognizing not only the explicit expectations, but also the implicit assumptions each brings with them. The following is a list of some of the characteristics and skills identified in this document as essential for the associate/mentor role: teaching experience including a diverse repertoire of styles and strategies; effective interpersonal communication skills; personal and professional integrity; the ability of the associate/mentor teacher to model problem solving in the classroom; the interest and willingness of the associate/mentor teacher to embrace the role as a 'co-learner'; and, their ability to support and encourage the teacher candidate in the development of their teaching practice.

Mentoring relationships may take a variety of forms including: the one-to-one mentoring relationship; a mentor community which may include 'peer support groups,' and finally, what is referred to as 'cybermentoring,' using online relationships to build supportive networks. The findings of this study consistently articulated the associate participants' expectation surrounding a need for active collaboration with the faculty - particularly with faculty advisors, to make the connection between theory and experience. A mentor community, as an integral aspect of a community of practice, may speak to this by supporting, valuing, and integrating the theoretical knowledge obtained by teacher candidates through university instruction, with the working knowledge gained during field experience [18].

Roth and Boyd assert that what makes practitioners competent is the knowledge gained through coparticipation with competent others in a community of practice [13]. They refer to this as 'coparticipation in practice' in a teaching-learning environment that fosters competency. Furthermore, research conducted by Roth, Masciotra and Boyd recommends that relationships between university and schools emphasize learning through co-teaching as a method to foster the development of shared experiences between the associate and teacher candidate, and most importantly in terms of relationship building, a basis for mutual understanding [14]. This parallels the findings of research conducted by Larson and Coebel in which co-learning opportunities for associate/mentors and teacher candidates, developed through a partnership between the school and the university, were seen as methods to facilitate the theory-to-practice connection for teacher candidates [8]. As Roth and Boyd claim, teaching is tied with the experience of being in the classroom, and development of active knowlegeability, what they claim is, "...a form of embodied knowing acquired in praxis" [13; 65]. Further, it may be argued that this is congruent with the aims of a community of practice, in that as they assert, "...coteaching affords tremendous learning 
experiences not only for preservice teachers but also for practising school and university teachers trying to understand the lifeworlds of teaching and trajectories of competencies in these lifeworlds" [ $13 ; 65]$

At the University of Windsor, Faculty of Education, we are currently developing a number of initiatives to address the findings of this study and thereby strengthen the relationship amongst the members of the triumvirate (associate/mentor teacher, teacher candidate, faculty). With regard to the need identified in the study for associate teacher orientation, and clarification of role expectations, the faculty has launched a series of newsletters entitled, Field Notes: A Newsletter for Associate/Mentor Teachers. The first issue addressed the 'Role of the Associate/Mentor Teacher' and headings of discussion included: welcoming the teacher candidate; theory into practice; teaching practice; and general information about providing feedback to teacher candidates. The second issue specifically addressed tips and suggestions for associate/mentor teachers in providing oral and written feedback to teacher candidates. The third newsletter covered the assessment and evaluation of the practicum - tips and suggestions for associate/mentor teachers.

Another resource created to enhance communicative ties with associate teachers is the virtual learning community the Faculty of Education created entitled the, Associate Teacher Learning Community (www.uwindsor.ca/atlc). This website provides associate/mentor teachers with general information about the field experience component of pre-service teacher education including: pre-service calendars, field experience handbooks, listing of events; a section specifically dealing with the associate teacher role as mentor including a self assessment instrument - mentorship survey; information about assessment and evaluation of the practicum; and various resources and links of interest for associate teachers. In addition, this website houses a series of learning objects in the form of video vignettes which were created to engage directly with associate teachers in a community of practice - to share effective mentoring strategies, and to promote continuous learning in the teaching profession.

The learning object videos housed on the Associate Teacher Learning Community (ATLC) website include: Defining a Community of Practice (What is a community of practice? How can the development of collegial relationships between the teacher candidate and their school colleagues impact the practicum experience?); Teacher Candidate Mentorship Program (What is the purpose of 'inschool' reflection journals? Who selects the topics for these journals? Is the in-school observation component discussed in these journals? Who reads these reflective journals?); Welcoming the Teacher Candidate (Recommendations for enhancing teacher candidate learning opportunities including: the observation component of the practicum, the practicum itself - communicating classroom routines, procedures \& set-up); Supporting Internationally Educated Teacher Candidates (Guiding and supporting internationally educated teacher candidates in Ontario classrooms: What is a community of practice in the teaching profession in Ontario? Can a community of practice impact the practicum experience for internationally educated teacher candidates - how and why?); Supporting OnGoing Professional Growth (A teacher candidate/faculty advisor portfolio conference); and A Teacher Candidate Review of the Professional Growth Portfolio.

\section{Conclusion}

In conclusion, it may be that the reciprocity of the learning experience associated with mentorship relationships in fact provides the necessary supports to critically transform education in schools by allowing both mentor and mentee to expand their 'mindscape' of teaching beyond a traditional approach [12]. Wenger and Snyder in defining the purpose of a community of practice, state that it is to “...develop members' capabilities; to build and exchange knowledge" [19;142]. And furthermore, that the dynamic nature of a community of practice involves learning on the part of all the members. Therefore, in seeking to strengthen the triumvirate relationship in pre-service teacher education, and to support a community of practice, there are essential questions that must be considered: Do we, as members of an educational community of practice involved in teacher education, want teacher candidates to learn only the current methods/forms of teaching in schools? Or, can the development of mentorship relationships and collaborative opportunities which support communities of practice, work to enrich the professional culture of teachers and teaching? As one of the study participant indicated, this is a shared responsibility facing both associates and the faculty, and what they identified as the need, "to ensure our educational system is getting the best possible future teachers."

The findings of this study will be used to continue the development of future initiatives to enhance the triumvirate relationship as an essential component of the pre-service program, and to support a community of practice which integrates theory and practice in pre-service teacher education. 


\section{References}

[1] Beck, C. \& Kosnik, C. (2000). Associate teachers in pre-service education: clarifying and enhancing their role. Journal of Education for Teaching, (26)3, pp. 207-224.

[2] Beck, C. \& Kosnik, C. (2002, Spring). Components of a good practicum placement: Student teacher perceptions. Teacher Education Quarterly, (29) 2, pp. 81-98.

[3] Duquette, C. (1996, Winter). Partnerships in preservice education: Perceptions of associate teachers and student teachers. McGill Journal of Education (31)1, pp.69-81.

[4] Faire, M. (July 1994). Improving the practicum: the professional development needs of lecturers, associate teachers and student teachers. Paper presented at the Annual Conference of the Australian Teacher Education Association $\left(24^{\text {th }}\right.$, Brisbane, Queensland, Australia, July 36, 1994).

[5] Ferrier-Kerr, J. L. (2009). Establishing professional relationships in practicum settings. Teaching and Teacher Education, 25(6), pp. 790-797.

[6] Goodnough, K., Osmond, P., Dibbon, D., Glassman, M. \& Stevens, K. (2009, February). Exploring a triad model of student teaching: Pre-service teacher and cooperating teacher perceptions. Teaching and Teacher Education, 25(2), pp. 285-296. Retrieved January 23, 2010, from: http://journals1.scholarsportal.info.ezproxy.uwindsor.ca/tm p/4108924408591643302.pdf

[7] Joong, P. (May 27, 2007). Teacher Education Practicum in Ontario. Presentation at CSSE. Saskatoon, SK.

[8] Larson, W. C. \& Goebel, A. J. (2008, May). Putting theory into practice: a professional development school/university co-teaching project. Journal of the Scholarship of Teaching and Learning, 8(2), pp. 52-61.

[9] Macdonald, C.J., Baker, D., \& Stewart, S.R. (1995, Winter). Student teachers in the classroom: Associate teachers' perspectives. McGill Journal of Education, (30)1, pp. 73-95.

[10] Mujawamariya, D. (2001). Associate teachers facing integration of visible minorities into the teaching profession in Francophone Ontario. Canadian Ethnic Studies, (33)2, p. 78. Retrieved July 19, 2007, from: http://proquest.umi.com/pqdlink?Ver=1\&Exp=04-062014\&FMT $=7 \&$ DID $=348264231 \&$ RQT $=309$

[11] Neil, R. (1993, Fall) Practicum associates' views on their role and the program of pre-service education. Education Canada, (33)3, p.8. Abstract retrieved electronically July $19, \quad 2007$ : http://proquest.umi.com/pqdlink?vinst=PROD\&fmt=3\&sta rtpage $=-$

$1 \&$ ver $=1 \&$ clientid $=2241 \&$ vname $=P Q D \& R Q T=309 \&$ did $=$ 705555591\&exp=04-06- 2014\&scaling $=$ FULL\&ts $=1239132901 \&$ vtype $=$ PQD\&rqt $=$ $309 \&$ TS $=1239132944 \&$ clientId $=2241$

[12] Osterman, K.F. (1990, February 2). Reflective practice: A new agenda for education. Education and Urban Society, 22(2), 133-152.

[13] Roth, W. M. \& Boyd, N. (1999). Coteaching, as colearning, is praxis. Research in Science Education, 29(1), pp. 51-67.

[14] Roth, W. M., Masciotra, D. \& Boyd, N. (1999). Becoming-in-the-classroom: a case study of teacher development through coteaching. Teaching and Teacher Education, 15, pp.771-784.

[15] Tuckman, B.W. (1976, Fall). The Tuckman teacher feedback form (TTFF). Journal of Educational Measurement, (13)3, pp.233-237.

[16] University of Western Ontario, Faculty of Education, Continuing Education. Mentoring: Tips and ideas for teachers and administrators $\left(3^{\text {rd }}\right.$ ed.). London, ON: Author. Retrieved January 23, 2010, from: http://www.edu.uwo.ca/conted/mentor/topic2.html

[17] University of Windsor, Faculty of Education, Field Experience Handbook, Consecutive Program 2009-2010. (2009). Windsor, ON: Author. Retrieved January 27, 2010, from:

http://web4.uwindsor.ca/units/edu/FacOfEd.nsf/cf50c73c2 3e058b985256db30060a59e/93e61 ca55bcaacf4852573470 0743be4/\$FILE/CONSECUTIVE\%20Field\%20Experience \%20Handbook\%2009-10.pdf

[18] Viskovic, A. (2006, November). Becoming a tertiary teacher: Learning in communities of practice. Higher Education Research \& Development, 25(4), 323-339.

[19] Wenger, E. C. \& Snyder, W. M. (200, January/February). Communities of practice: The organizational frontier. Harvard Business Review, 78(1), pp. 139-145. Retrieved January 23, 2010, from: http://web.ebscohost.com.ezproxy.uwindsor.ca/ehost/detail ?vid=4\&hid=108\&sid=29681e1b-799b-4af9-bcf9d91a4e355893\%40sessionmgr110\&bdata =JnNpdGU9ZWh vc3QtbGl2ZQ $\% 3 \mathrm{~d} \% 3 \mathrm{~d} \# \mathrm{db}=\mathrm{bth} \& \mathrm{AN}=2628915$ 